\title{
LEKSIKON SAMIN SEBAGAI CERMIN PANDANGAN DUNIA PENUTURNYA
}

\author{
Suhandano \\ Fakultas Ilmu Budaya Universitas Gadjah Mada \\ email: suhandano@ugm.ac.id
}

\begin{abstract}
Abstrak
Masyarakat Samin merupakan bagian dari penutur bahasa Jawa. Akan tetapi, bahasa Jawa yang mereka tuturkan dalam beberapa hal sedikit berbeda dengan bahasa Jawa pada umumnya. Misalnya, mereka menggunakan sejumlah leksikon yang khas seperti rukunan 'suami/isteri', pondhokan 'rumah', turun 'anak', dan sebagainya. Tulisan ini membicarakan leksikon khas dalam masyarakat Samin dengan tujuan untuk menjelaskan mengapa mereka menggunakan sejumlah leksikon khas tersebut. Pembicaraan dilakukan dengan pendekatan linguistik antropologis yang melihat fakta bahasa dalam konteks sosial budaya yang luas. Hasilnya mengungkapkan bahwa penggunaan leksikon khas pada masyarakat Samin tidak bersifat kebetulan, tetapi berkaitan dengan cara pandang mereka terhadap hal yang dilabeli oleh leksikon tersebut; dan bagaimana mereka memandang hal yang dilabeli oleh leksikon tersebut dipengaruhi oleh ideologi Saminisme. Selain itu, terungkap pula bahwa dalam beberapa hal leksikon bagi masyarakat Samin bukan hanya sekadar label yang menandai sesuatu, tetapi juga menjadi alat dalam menafsirkan sesuatu.
\end{abstract}

Kata kunci: leksikon, saminisme, pandangan dunia

\section{THE SAMIN LEXICON AS A REFLECTION OF THE SPEAKERS' WORLDVIEW}

\begin{abstract}
The Samin people are a group of Javanese speakers. However, the Javanese they use is a little different from the common Javanese in some ways. For example, they use some distinctive lexicons such as rukunan 'husband/wife', pondhokan 'house', turun 'child', and so on. This article discusses the distinctive lexicons in the Samin community to explain why they use such unique lexicons. The discussion employs the framework of anthropological linguistics studying linguistic facts in a broad sociocultural context. The findings reveal that the use of distinctive lexicons by the Samin community is not coincidental, but related to their perspectives on viewing things labeled by the lexicons; how they do so is influenced by the Saminism ideology. In addition, it is also revealed that in some instances, for the Samin community, the lexicons are not just labels that mark something, but also tools to interpret something.
\end{abstract}

Keywords: lexicon, Saminism, worldview

\section{PENDAHULUAN}

Sebagaimana diceritakan oleh Widodo (1997), di sebuah desa di Kabupaten Pati pada 7 Agustus 1989 pemerintah menikahkan secara massal 117 pasangan orang Samin. Mereka sebenarnya telah menikah, tetapi pernikahan mereka belum dianggap sah oleh pemerintah. Hal itu terjadi karena pernikahannya baru dilaksanakan menurut kepercayaan mereka, belum dilaksanakan sesuai dengan salah satu agama yang diakui oleh pemerintah. 
Agar pernikahan mereka menjadi sah atau resmi, mereka harus dinikahkan lagi dan pernikahannya harus dilaksanakan sesuai dengan ketentuan dalam agama tertentu. Oleh karena itu, mereka diminta untuk memilih salah satu agama guna pelaksanaan pernikahan tersebut. Hal yang menarik adalah ternyata mereka memilih agama Budha. Alasan utamanya adalah karena menurut mereka nama agama tersebut sesuai dengan salah satu ajaran dalam kepercayaan mereka, yaitu ajaran sikep rabi (melakukan hubungan seksual). Mereka menafsirkan bahwa nama agama tersebut berasal dari frase bahasa Jawa mlebune uda (masuknya telanjang), yang menggambarkan keadaan ketika orang melakukan hubungan seksual.

Bahwa nama agama Budha berasal dari kependekan frase bahasa Jawa mlebune uda tentulah tidak benar, tetapi demikianlah masyarakat Samin menafsirkannya. Selanjutnya, apakah mereka akan menjalankan ajaran agama Budha setelah pernikahan tersebut, hal itu juga belum dapat dipastikan karena mereka telah memiliki kepercayaan sendiri. Pemilihan agama tersebut tampaknya lebih pada pertimbangan untuk keperluan mengesahkan perkawinan mereka saja. Namun dari sisi linguistik, ada hal penting yang perlu dicatat dari peristiwa itu, yaitu bahwa mereka memikirkan agama, dalam hal ini agama Budha, berdasarkan pada nama atau leksikon yang digunakan untuk menandai agama tersebut.

Cara masyarakat Samin dalam memikirkan sesuatu dengan berpijak pada leksikon yang menandai sesuatu tersebut tidak hanya terjadi dalam memilih agama pada peristiwa pernikahan masal yang sudah berlangsung lebih dari seperempat abad yang lalu. Sampai sekarang pun dalam memikirkan beberapa hal mereka masih menggunakan cara seperti itu. Sebagai contoh, ketika ditanya mengapa sebagian masyarakat Samin tidak menyekolahkan anaknya, seorang warga
Samin menjawab dengan menjelaskan arti kata sekolah. Menurutnya, sekolah berasal dari frase bahasa Jawa seseking polah, (seseg berarti 'sesak' dan polah berarti 'tindakan, perilaku'). Dia mengemukakan bahwa yang berkewajiban mendidik anak atau membentuk polah anak adalah orang tuanya. Hanya saja, ketika orang tua sudah tidak mampu lagi atau sudah merasa sesak dalam mengarahkan polah anaknya, mereka dapat mengirimkannya ke sekolah. Itulah sebabnya, katanya, sampai sekarang masih ada sebagian orang Samin yang tidak menyekolahkan anaknya karena mereka merasa masih mampu dalam mengarahkan polah anaknya.

Demikianlah, leksikon bagi masyarakat Samin bukan hanya sekadar sederetan bunyi yang menandai sesuatu, tetapi juga menjadi alat untuk memikirkan sesuatu. Tulisan singkat ini akan membicarakan sejumlah leksikon khas pada masyarakat Samin dengan memaparkan penafsiran di balik pemakaian leksikon tersebut. Diharapkan dari pemaparan ini beberapa hal yang mungkin dianggap 'aneh' pada orang Samin dapat dipahami sehingga tidak terjadi salah penafsiran terhadap mereka. Maklumlah, selama ini masih ada anggapan yang kurang tepat pada sebagian orang terhadap masyarakat Samin berkaitan dengan bahasa yang mereka tuturkan.

Dalam studi linguistik bahwa leksikon atau lebih luasnya bahasa berkaitan dengan cara berpikir penuturnya sudah lama dikemukakan oleh para ahli. Humbolt, misalnya, mengemukakan bahwa "each language ... contains a characteristic worldview" (Wierzbicka, 1992:3). Pernyataan Humbolt ini dipertegas lagi oleh Boas (1964a) dengan mengatakan bahwa " ... the conciseness and clearness of thought of people depend to a great extent upon their language". Sapir dan Whorf,yang dalam teori linguistik pemikirannya dikenal dengan nama hipotesis Sapir-Whorf, juga mengatakan hal yang senada. Menurut dua 
pakar linguistik ini, bahasa membentuk persepsi manusia terhadap realitas dunia (Sampson, 1980).

Bahasa terbangun atas sejumlah unsur dan leksikon merupakan unsur bahasa yang menonjol untuk menunjukkan perbedaan cara pandang penuturnya. Hal yang sama dapat diacu dengan leksikon yang beragam dalam bahasa yang berbeda. Keberagaman leksikon tersebut tidak hanya dapat dilihat dari perbedaan bentuknya, tetapi juga jumlahnya. Sebagaimana ditunjukkan oleh Boas (1964b), misalnya, benda yang dalam bahasa Inggris hanya diacu dengan satu leksikon snow, dalam bahasa Eskimo benda tersebut diacu dengan empat leksikon, yaitu aput 'snow on the ground', qana 'falling snow', piqsirpoq 'drifting snow', dan qimuqsuq 'a snowdrift'. Perbedaan ini, menurut Boas, tergantung pada the chief interest of the people. Hal yang sama juga dapat dilihat pada perbedaan leksikon dalam Inggris dan Indonesia. Benda yang dalam bahasa Inggris hanya diacu dengan satu leksikon rice, dalam bahasa Indonesia diacu dengan empat leksikon: padi, gabah, beras, dan nasi.

Wierzbicka (1997) telah menunjukkan bahwa melalui analisis yang mendalam terhadap leksikon dapat diungkapkan perbedaan pandangan penutur bahasa. Ditunjukkan, misalnya, penutur bahasa Inggris berbeda dengan penutur bahasa Rusia dalam memikirkan tentang teman yang dalam kedua bahasa diacu dengan leksikon friend dan drug. Makna kedua leksikon ini tidaklah sama, terdapat unsur makna dalam leksikon friend yang tidak terkandung dalam leksikon drug; dan demikian pula sebaliknya terdapat unsur makna dalam leksikon drug yang tidak terkandung dalam leksikon friend. Wierzbicka juga menunjukkan bahwa tidak semua orang sama dalam memikirkan makna 'kebebasan'. Bahasa memiliki leksikon yang berbeda untuk konsep tersebut; bahasa Inggris memiliki leksikon freedom dan liberty, bahasa Latin memiliki leksikonlibertas, dan bahasa $\mathrm{Ru}-$ sia memiliki leksikon svoboda, volja, dan wolnosc. Meskipun terdapat kemiripan makna pada leksikon-leksikon ini, makna leksikon-leksikon tersebut tidaklah sama. Perbedaan makna ini mengindikasikan bahwa penutur ketiga bahasa berbeda dalam memikirkan 'kebebasan'. Lebih jauh Wierzbicka menyimpulkan bahwa leksikon dapat merupakan kunci dalam mengungkapkan etnososiologi, psikologi kultural, sejarah, politik, dan nilai-nilai budaya penutur bahasa.

Demikianlah dalam tulisan ini diikuti pendapat bahwa leksikon mencerminkan dan menceriterakan karakteristik cara hidup dan cara berpikir penuturnya sehingga dapat memberi petunjuk yang sangat bernilai dalam upaya memahami budaya penuturnya. Sebagaimana dikatakan oleh Wierzbicka (1997:4) bahwa "... the meaning of words from different languages reflect and pass on ways of living and ways of thinking characteristic of a given society (or speech community) and that they provide priceless clues to the understanding of culture. Meskipun demikian, perlu dicatat bahwa pembicaraan perbedaan leksikon dalam tulisan ini tidak bersifat lintas bahasa, sebagaimana pernyataan Wierzbicka tersebut, tetapi perbedaan leksikon lintas kelompok penutur dalam bahasa yang sama. Dalam hal ini yang dibicarakan adalah perbedaan leksikon pada kelompok penutur bahasa Jawa, yaitu leksikon yang digunakan oleh masyarakat Samin yang berbeda dari penutur bahasa Jawa pada umumnya.

\section{METODE}

Penelitian ini menggunakan pendekatan linguistik antropologis. Sebagaimana diketahui, dalam penelitian bahasa terdapat dua pendekatan utama dalam melihat fenomena bahasa. Pendekatan yang pertama melihat fenomena bahasa sebagai sesuatu hal yang bersifat oto- 
nom, terpisah dari hal lain di luar bahasa. Pendekatan yang kedua melihat fenomena bahasa dalam kaitannya dengan hal lain di luar bahasa. Linguistik antropologis termasuk dalam pendekatan yang disebut terakhir. Linguistik antropologis melihat fenomena bahasa dalam konteks sosial budaya penuturnya dengan tujuan untuk mengungkap makna tersembunyi di balik bahasa. Linguistik antropologis menafsirkan fenomena bahasa untuk mendapatkan pemahaman budaya penuturnya (Foley, 2001: 3-5). Dipilihnya pendekatan linguistik antropologis berdasarkan pertimbangan pada unit analisis kebahasaan dan pertanyaan yang hendak dijawab melalui penelitian ini. Unit analisis kebahasaan dalam penelitian ini adalah leksikon khas orang Samin dan pertanyaan yang hendak dijawab ialah mengapa mereka menggunakan leksikon khas tersebut.

Data penelitian yang berupa leksikon khas yang digunakan orang Samin diperoleh melalui melalui observasi partisipasi pada beberapa peristiwa tutur dengan sejumlah orang Samin di beberapa tempat di wilayah Kabupaten Pati, Kudus, dan Blora. Digunakannya metode observasi partisipasi ini sesuai dengan pernyataan Ahearn (2012: 35) bahwa metode observasi partisipasi merupakan metode yang paling banyak digunakan dalam penelitian etnografi, bahkan merupakan metode yang esensial untuk mengumpulkan data dalam penelitian antropologi linguistis (linguistik antropologis). Tuturan dalam peristiwa tutur yang diamati direkam, dan beberapa hal penting yang berkaitan dengan konteks tuturan dicatat. Selain itu, data yang berupa leksikon khas Samin juga dikumpulkan dari beberapa penelitian yang sudah ada seperti penelitian Widodo (1997) dan Mardikantoro (2012).

Dari observasi partisipasi dan penelitian terdahulu diperoleh data berupa sejumlah leksikon yang diperkirakan khas Samin. Untuk memastikan bahwa leksikon yang telah dikumpulkan adalah khas Samin peneliti mengeceknya dengan tuturan masyarakat penutur bahasa Jawa lain yang tinggal di sekitar masyarakat Samin dan penutur bahasa Jawa lainnya. Data selanjutnya dianalisis dengan menafsirkan maknanya. Penafsiran makna dilakukan dengan mempertimbangkan konteks, konteks dalam pengertian yang luas, dan hal-hal lain yang diperkirakan turut membangun makna leksikon. Hasil penafsiran kemudian dikonfirmasikan kepada beberapa orang Samin melalui wawancara. Dari hasil wawancara selain dapat diketahui apakah penafsiran yang dibuat tepat ataukah tidak, juga diketahui informasi tambahan yang dapat memperjelas penafsiran.

Ilustrasi berikut ini dapat memberi gambaran lebih konkret bagaimana penelitian ini dilaksanakan. Melalui observasi diperoleh data bahwa masyarakat Samin menggunakan dua leksikon untuk 'anak' yaitu leksikon anak dan turun. Dari hasil analisis diperoleh kesimpulan bahwa leksikon anak digunakan oleh ibu dan leksikon turun digunakan oleh ayah untuk menyebut anaknya. Hasil penafsiran ini lalu dikonfirmasi kepada orang Samin dan memang demikianlah faktanya. Melalui wawancara lalu digali alasan mengapa terdapat pembedaan seperti itu. Hasilnya adalah bahwa masyarakat Samin melakukan pembedaan seperti itu karena mereka ingin berbicara yang benar, berbicara yang sesuai dengan kenyataan. Ibu menyebut anaknya dengan leksikon anak karena ibulah yang manak'melahirkan' atau yang nganakke 'mengadakan'; sementara ayah tidak manak, tetapi hanya menurunkan sehingga ayah tidak menyebut anaknya dengan leksikon anak, melainkan dengan leksikon turun. Demikianlah masyarakat Samin ingin berbicara sesuai dengan kenyataan dan mengapa mereka berbicara demikian karena ideologi Saminisme yang mereka anut mengajarkan kejujuran. 
Demikianlah, gambaran garis besar jalannya penelitian yang ditempuh dalam menghasilkan tulisan ini. Dalam beberapa kasus jalannya penelitian tidak sesederhana seperti yang diilustrasikan di atas, tetapi lebih rumit dari itu. Kerumitan terutama pada tahap analisis yang berupa penafsiran untuk menemukan hal-hal yang dapat dikonfirmasi pada responden dan menggali lebih jauh latar belakang atau alasan pemakaian leksikon.

\section{HASIL DAN PEMBAHASAN}

Terdapat beberapa leksikon yang dapat dikategorikan sebagai leksikon khas Samin seperti garapan, pengaran, pondhokan, rukunan, salin sandhangan, turun, dan sebagainya. Leksikon ini sebenarnya juga dikenal oleh penutur bahasa Jawa pada umumnya, tetapi makna leksikon tersebut berbeda dari makna yang ada pada masyarakat Samin. Sebagai contoh, bagi penutur bahasa Jawa pada umumnya makna leksikon garapan (yang berasal dari garap 'kerja' dan imbuhan -an) adalah sesuatu yang dikerjakan, sedangkan masyarakat Samin memaknainya sebagai sawah. Demikian pula leksikon salin sandhangan, bagi penutur bahasa Jawa pada umumnya leksikon tersebut berarti berganti pakaian, sedangkan bagi masyarakat Samin salin sandhangan berarti mati. Pertanyaan yang muncul adalah mengapa masyarakat Samin menggunakan leksikon yang berbeda untuk menandai hal yang dalam bahasa Jawa sebenarnya sudah tersedia leksikon untuk menandainya? Mengapa masyarakat Samin harus menggunakan lesikon salin sandhangan untuk menyebut mati sehingga menjadi berbeda dari penutur bahasa Jawa pada umumnya?

\section{Leksikon sebagai Cermin Cara Pandang}

Leksikon atau kata terbangun atas dua unsur, yaitu bentuk dan makna atau penanda dan petanda. Selama ini dipahami bahwa hubungan antara penanda dan petanda bersifat semena atau arbitrer, kecuali untuk kata onomatope (tiruan bunyi) dan kata seru (Saussure, 1988:148150). Jadi, tidak ada alasan yang dapat menjelaskan mengapa untuk hal yang sama dalam bahasa Jawa dan Indonesia disebut dengan leksikon mati, tetapi dalam bahasa Inggris disebut dengan leksikon die, dan dalam bahasa Arab disebut dengan leksikon maut. Akan tetapi, apakah sifat arbitrer ini juga berlaku pada perbedaan leksikon pada penutur bahasa Jawa pada umumnya dan masyarakat Samin? Dengan kata lain, apakah perbedaan leksikon pada penutur bahasa Jawa pada umumnya dengan masyarakat Samin hanya bersifat kebetulan, tidak terdapat hal yang melatarbelakanginya? Tidak.

Jika perbedaan leksikon pada masyarakat Samin dan penutur bahasa Jawa pada umumnya bersifat kebetulan, atau hanya bersifat variasi dialektal saja, leksikon yang digunakan oleh masyarakat Samin akan sama dengan leksikon yang digunakan penutur bahasa Jawa lainnya yang tinggal berdekatan dengan masyarakat Samin. Kenyataannya tidak demikian. Sebagai contoh, penutur bahasa Jawa yang tinggal di sekitar masyarakat Samin menggunakan leksikon mati, tidak menggunakan leksikon salin sandhangan untuk menyebut mati. Selain itu, masyarakat Samin yang tinggal berjauhan jaraknya menggunakan leksikon yang sama. Masyarakat Samin yang tinggal di Kemantren, Blora menggunakan leksikon yang sama dengan yang digunakan oleh masyarakat Samin yang tinggal di Sukalila, Pati. Masyarakat Samin di kedua tempat itu, misalnya, menggunakan leksikon salin sandhangan untuk menyebut mati. Lagi pula, jika perbedaan leksikon pada masyarakat Samin dan penutur bahasa Jawa pada umumnya hanya bersifat kebetulan, mengapa leksikon yang digunakan masyarakat Samin adalah salin sandhangan, bukan leksikon yang lain. 
Dengan demikian, jelaslah bahwa perbedaan leksikon pada masyarakat Samin dan penutur bahasa Jawa pada umumnya tidak bersifat kebetulan atau hanya merupakan variasi dialektal, melainkan ada hal yang melatarbelakanginya.

Hal yang melatarbelakangi perbedaan leksikon tersebut berkaitan dengan cara pandang mereka terhadap hal yang ditandai dengan leksikon. Sebagai contoh, seorang warga Samin menuturkan bahwa mati bukan berarti berakhirnya kehidupan seseorang. Menurut dia orang yang mati sebenarnya masih hidup, masih ada di sekitar kita. Hanya saja, orang yang mati tidak lagi memakai pakaian yang berupa tubuh yang dipakainya selama ini. Tubuhnya sudah tidak dapat dipakai lagi sehingga harus diganti dengan pakaian yang lain. Itulah sebabnya masyarakat Samin menyebut mati dengan leksikon salin sandhangan yang berarti berganti pakaian. Demikianlah, digunakannya leksikon salin sandhangan untuk menyebut mati pada masyarakat Samin berkaitan dengan cara mereka dalam melihat kematian.

Digunakannya leksikon rukunan untuk menyebut suami atau isteri pada masyarakat Samin juga dilatarbelakangi cara pandang mereka terhadap suami atau isteri. Seperti diketahui penutur bahasa Jawa pada umumnya menyebut isteri atau suami dengan leksikon bojo, tetapi masyarakat Samin menyebutnya dengan leksikon rukunan. Suami atau isteri dalam pandangan masyarakat Samin adalah orang yang telah bersedia hidup rukun dengan kita. Oleh karena itu, orang tersebut disebut rukunan. Bagi mereka, penyebutan suami atau isteri dengan leksikon bojo sebagaimana yang berlaku pada penutur bahasa Jawa pada umumnya tampaknya kurang dapat memberikan gambaran bagaimana suami atau isteri harus dipandang atau diperlakukan. Ajaran Saminisme mengajarkan agar suami isteri selalu hidup rukun dan leksikon untuk menyebut suami atau isteri menjadi salah satu alat untuk melaksanakan ajaran ini. Dari observasi dan laporan beberapa informan diperoleh fakta bahwa di kalangan masyarakat Samin kehidupan suami isteri selalu tampak rukun, bahkan konon tidak ada poligami dan perceraian.

Perbedaan cara pandang masyarakat penutur bahasa Jawa pada umumnya dengan masyarakat Samin juga dapat ditemukan pada perbedaan leksikon untuk sawah. Masyarakat Samin mengacu sawah dengan leksikon garapan. Lesikon merupakan kata polimorfemik yang berasal dari bentuk dasar garap 'kerja' dan akhiran-an sehingga berdasarkan unsur yang membentuknya garapan berarti sesuatu yang dikerjakan. Akan tetapi, masyarakat Samin memaknai lesikon tersebut lebih sempit dari makna tersebut. Mengapa sesuatu yang dikerjakan bagi masyarakat Samin hanya berarti sawah, tidak meliputi hal yang lain. Hal ini tampaknya berkaitan dengan pandangan masyarakat Samin bahwa pekerjaan pokok orang di dunia ini adalah bercocok tanam untuk menghasilkan pangan. Pekerjaan masyarakat Samin adalah bertani, mereka tidak mau bekerja di sektor lain, berdagang misalnya. Saminisme mengajarkan seperti itu. Oleh karena itu, mereka menyebut sawah dengan leksikon garapan karena hanya sawahlah yang harus digarap.

Contoh lain dari penggunaan leksikon khas Samin yang dilatarbelakangi perbedaan cara pandang adalah penggunaan leksikon njaluk 'minta'. Baik penutur bahasa Jawa pada umumnya maupun masyarakat Samin menggunakan leksikon ini. Penutur bahasa Jawa pada umumnya dapat menggunakan leksikon ini untuk, misalnya, meminta air yang terdapat di sumur tetangganya. Masyarakat Samin, akan tetapi, tidak menggunakan leksikon itu untuk maksud tersebut. Jadi, jika ada orang yang mau minta air di sumur milik orang Samin dengan berkata "Aku njaluk banyumu” yang berarti 'Saya minta airmu', kemungkinan besar orang Samin pemilik 
sumur tersebut akan diam saja. Hal itu, akan tetapi, tidak berarti bahwa pemilik sumur tersebut tidak mengizinkan sebagian air sumurnya diminta. Ia hanya berpikir bahwa kalimat yang digunakannya tidak tepat karena pemakaian leksikon njaluk di dalamnya. Bagi orang Samin, leksikon yang benar untuk kalimat tersebut bukan njaluk, melainkan nganggo 'memakai'. Dalam pandangan masyarakat Samin, air bukanlah milik seseorang, melainkan milik bersama sehingga ketika ada orang mau minta air yang ada di sumurnya, ia tidak tahu harus berkata apa. Air yang ada di dalam sumur itu bukan miliknya. Karena air tersebut bukan miliknya, ia tidak berhak membolehkan atau melarangnya ketika diminta. Hal itu berbeda ketika orang yang mau meminta air tersebut menggunakan leksikon nganggo, orang Samin pemilik sumur tersebut akan mempersilakannya karena air memang milik bersama sehingga dapat dipakai bersama.

Masih terdapat beberapa leksikon lain yang dapat digunakan untuk menjelaskan bahwa penggunaan leksikon tertentu pada masyarakat Samin, yang berbeda dengan penutur bahasa Jawa pada umumnya, berkaitan dengan cara pandang mereka terhadap hal yang dilabeli oleh leksikon tersebut. Namun, pemaparan terhadap pemakaian beberapa leksikon di atas tampaknya sudah cukup untuk menjelaskan bahwa digunakan leksikon tertentu pada masyarakat Samin tidaklah bersifat kebetulan, tetapi berkaitan dengan pandangan dunia mereka, dan pandangan dunia tersebut bersumber dari ajaran Saminisme yang mereka anut.

\section{Leksikon sebagai Cermin Sikap Jujur}

Saminisme mengajarkan banyak hal mengenai kehidupan yang baik kepada para penganutnya, di antaranya sikap jujur. Menurut Mardikantara (2012: 105107) kejujuran merupakan inti ajaran Saminisme. Dalam apa yang disebut se- bagai Angger-Angger Pangucap (Ketentuan dalam Berbicara) terdapat ungkapan putih putih, abang abang 'jika putih katakanlah putih, jika merah katakanlah merah'. Maksudnya, orang harus berbicara sesuai dengan fakta, tidak boleh bohong. Di kalangan orang Samin juga terdapat ungkapan sing ana neng ati, ya iku sing bakal metu saka cangkem 'yang ada dalam hati, itulah yang akan keluar dari mulut' yang bermakna bahwa orang harus berani mengatakan apa yang dirasakan, dipikirkan.

Sikap jujur yang dipegang oleh orang Samin dalam praktik kehidupan seharihari ini juga tercermin dalam beberapa leksikon yang mereka gunakan. Sebagai contoh, orang Samin menggunakan dua leksikon untuk menyebut anak, yaitu leksikon anak dan leksikon turun, leksikon anak digunakan oleh ibu dan leksikon turun digunakan oleh ayah. Pada penutur bahasa Jawa pada umumnya tidak terdapat pembedaan seperti itu. Mengapa masyarakat Samin harus menggunakan dua leksikon, bukankah satu leksikon saja sudah cukup.Tidak. Seorang lakilaki Samin mengemukakan bahwa jika ia menyebut anaknya dengan leksikon anak sebagaimana yang digunakan oleh isterinya, maka ia telah berbohong. Menurutnya, laki-laki tidak manak 'melahirkan' atau tidak nganakke 'mengadakan'; yang manak atau nganakke adalah isterinya, sedangkan suami hanya menurunkan. Oleh karena itu, agar sesuai dengan kenyataan yang ada, dalam pandangan masyarakat Samin yang dapat menyebut anak adalah ibu, sedangkan ayah menyebutnya dengan turun.

Berikut adalah contoh pemakaian leksikon lain yang mencerminkan bagaimana masyarakat Samin berusaha menghadirkan kejujuran dalam tuturan mereka. Dalam sebuah percakapan mengenai pertanian dengan salah seorang warga Samin, ditanyakan kepadanya mengenai bagaimana cara memberikan ilmu perta- 
nian yang diketahuinya kepada orang lain yang dalam bahasa Jawa diungkapkan dengan kalimat "Piye carane menehke ilmu marang wong liya". Orang Samin tersebut tidak segera menjawab pertanyaan itu, tetapi mengoreksi kalimat pertanyaan tadi dengan mengatakan bahwa pemakaian leksikon menehke 'memberikan' dalam kalimat tersebut tidak tepat. Menurut dia, jika seseorang menehke atau memberikan sesuatu kepada orang lain, maka sesuatu yang diberikan telah berpindah kepada orang yang diberi, tidak lagi berada pada orang yang memberi. Padahal, ketika ilmu diberikan kepada orang lain, ilmu itu masih ada pada orang yang memberikan sehingga pemakaian leksikon menehke pada frase menehke ilmu, menurut orang Samin tersebut, tidak benar atau ada unsur kebohongan di dalamnya. Dalam pandangan orang Samin ilmu tidak dinehke 'diberikan', tetapi diomongke 'dibicarakan' kepada orang lain.

Dari contoh di atas dapat disimpulkan bahwa setidaknya terdapat dua cara yang dilakukan masyarakat Samin dalam melihat leksikon sebagai cermin kejujuran. Pertama, mereka melihat leksikon dari unsur yang membentuknya. Hal ini terdapat pada pembedaan penyebutan anak dengan dua leksikon yaitu anak dan turun. Sorang ibu menyebut anaknya dengan leksikon anak karena dialah yang manak atau yang nganakke. Seorang ayah tidak dapat menyebut anaknya dengan leksikon anak karena dia tidak manak atau nganakke; ayah menyebut anaknya dengan leksikon turun karena dia hanya menurunkan anak. Kedua, masyarakat Samin menjaga agar makna kata bersifat tetap, konsisten. Hal ini dapat dilihat pada pemakaian leksikon menehke pada frase menehke ilmu yang dianggap tidak benar. Pada leksikon menehke terkandung makna terjadinya perpindahan sesuatu dari pihak yang memberi ke pihak yang diberi. Jika tidak terjadi perpindahan sesuatu, peristiwa yang dideskripsikan tidak dapat disebut sebagai menehke.
Perlu dikemukakan di sini bahwa dalam masyarakat Samin sikap jujur tidak hanya tercermin pada pemakaian leksikon tertentu, tetapi juga pada aspek kebahasaan yang lain. Bahkan, masyarakat Samin melihat bahwa tujuan pokok pendidikan di antaranya adalah membuat agar bahasa orang menjadi benar dalam arti tidak mengandung kebohongan di dalamnya. Seorang pemuka Samin mengatakan bahwa "sekolah iku kanggo ngapikna tumindak lan benerna ucapan" yang berarti bahwa tujuan sekolah adalah untuk memperbaiki perilaku/tindakan dan membetulkan ucapan.

\section{Bentuk sebagai Alat Pemaknaan}

Leksikon terbentuk dari dua unsur, yaitu bentuk dan makna. Hubungan keduanya bersifat semena atau arbitrer, merupakan kesepakatan penutur bahasa. Demikianlah pendapat yang selama ini diterima secara luas. Namun, bagi masyarakat Samin, jika hubungan antara bentuk dan makna sudah disepakati, penutur tidak lagi bebas untuk mengubahnya. Itulah yang berlaku pada beberapa leksikon meskipun mungkin tidak untuk semua leksikon. Sebagaimana dipaparkan dalam kasus leksikon menehke di atas, misalnya, leksikon tersebut telah disepakati untuk mendeskripsikan perbuatan memindahkan kepemilikan sesuatu dari seseorang ke orang lain. Jika dalam suatu perbuatan tidak terjadi pemindahan kepemilikan, seperti yang terdapat dalam frase menehke ilmu, perbuatan tersebut tidak dapat diacu dengan leksikon menehke sehingga frase tersebut dianggap tidak benar untuk mendeskripsikan perbuatan yang dimaksud. Selain itu, bagi masyarakat Samin leksikon yang sudah disepakati maknanya harus pula digunakan secara konsisten. Hal ini dapat dilihat pada pemakaian leksikon anak yang hanya digunakan oleh ibu untuk menyebut anaknya karena ibulah yang manak atau nganakke 'melahirkan'. Ayah menyebut anaknya dengan turun 
karena ayah berperan nurunke 'menurunkan' anaknya, tidak melahirkannya.

Dalam masyarakat Samin terdapat beberapa contoh yang menunjukkan bahwa bentuk-bentuk yang sudah disepakati maknanya digunakan untuk memahami atau menafsirkan makna leksikon lain. Dengan kata lain, pemahaman terhadap makna sejumlah leksikon didasarkan pada makna leksikon lain. Leksikonleksikon tertentu dianggap berasal dari leksikon lain. Penentuan leksikon lain yang dianggap sebagai pembentuk leksikon tertentu tersebut didasarkan pada bentuknya. Sebagai contoh, seperti yang telah dikemukakan pada awal tulisan ini, masyarakat Samin menganggap bahwa nama agama Budha berasal dari leksikon mlebu 'masuk' dan (w)uda 'telanjang'. Mereka juga memandang bahwa leksikon sekolah berasal dari sesek 'sesak' dan polah 'tindakan, perbuatan, atau perilaku'. Karena leksikon tersebut dipandang terbentuk dari leksikon lain, mereka memahami leksikon tersebut berdasarkan makna leksikon lain yang membentuknya. Karena masyarakat Samin memahami leksikon sekolah sebagai seseking polah, mereka baru akan mengirim anaknya ke sekolah apabila mereka sudah merasa sesek atau tidak mampu lagi dalam mendidik polah anaknya. Ketika masih mampu mendidik anaknya, mereka tidak akan mengirimkan anaknya ke sekolah. Barangkali adanya pemahaman seperti itulah yang menjadi salah satu sebab mengapa sampai sekarang masih banyak anak-anak Samin yang tidak bersekolah.

Contoh leksikon lain yang maknanya ditafsirkan berdasarkan bentuknya adalah leksikon sholat. Seorang warga Samin menuturkan bahwa dia juga mengerjakan sholat. Ketika ditanya, kapan dia mengerjakan sholat, dia menjawab bahwa setiap saat dia mengerjakan sholat. Jawaban ini tentu sangat aneh karena sholat dalam agama Islam diatur waktu pelaksanaannya. Orang Samin tersebut menjelaskan bahwa sholat yang dia kerjakan bukan seperti sholat yang diajarkan dalam agama Islam. Menurut dia, sholat berarti solahing ilat 'gerakan lidah'. Yang dia maksud dengan mengerjakan sholat adalah menjaga gerakan lidah, artinya menjaga ucapannya. Dia menjaga ucapannya agar isinya selalu benar, sesuai dengan kenyataan atau tidak bohong; dia menjaga agar ucapannya tidak menyakiti orang lain; dia menjaga agar ucapannya tidak menimbulkan perselisihan atau pertengkaran sebagaimana yang diajarkan dalam Saminisme yang dia anut.

Penafsiran makna leksikon berdasarkan bentuknya pada masyarakat Samin ini tidak hanya dilakukan terhadap sejumlah leksikon yang berasal dari bahasa asing seperti Budha, sekolah, dan sholat; tetapi juga terhadap sejumlah leksikon dalam bahasa Jawa. Misalnya, leksikon bumi dianggap berasal dari mlebune diemi-emi 'masuk secara pelan-pelan'; sembahyang dianggap berasal dari mesem tambah nggrayang 'tersenyum lalu memegang'; wali dianggap berasal dari sing disuwali 'sesuatu yang ditutupi dengan pakaian'; gusti dianggap berasal dari bagusing ati 'bagusnya hati', dan sebagainya. Memang, dalam masyarakat Jawa pada umumnya juga terdapat penafsiran makna leksikon berdasarkan pada bentuknya seperti yang terdapat pada masyarakat Samin. Penafsiran makna seperti itu dalam bahasa Jawa disebut kerata basa. Hanya saja, dalam masyarakat Jawa kemiripan bentuk leksion dengan makna unsur yang membangun leksikon tersebut pada umumnya dianggap sebagai hal yang bersifat kebetulan saja, tidak seperti yang terdapat pada masyarakat Samin yang cenderung diyakini sebagai kebenaran.

Pemaparan di atas belum sepenuhnya dapat menjelaskan kekhasan leksikon Samin. Masih terdapat sejumlah leksikon khas Samin yang belum dapat dijelaskan alasan pemakaiannya. Sebagai contoh, ketika ditanya berapa usiamu "Pira umur- 
$m u$ " misalnya, orang Samin biasanya akan menjawab umur saya satu "Umurku siji". Hal ini, akan tetapi, tidak berarti bahwa umurnya memang baru satu tahun atau satu dasawarsa. Sebab, selain hal seperti itu tidak mungkin, ketika ditanya lebih lanjut mengapa demikian, mereka menjelaskan bahwa umur manusia memang hanya satu dan berlaku selama hidup. Menurut orang Samin "Umur ki ya mung siji dinggo saklawase". Demikianlah, terdapat perbedaan penafsiran terhadap makna leksikon umur pada masyarakat Samin dan penutur bahasa Jawa pada umumnya. Bagi masyarakat Samin umur merupakan satu kesatuan waktu yang utuh, tidak dapat dibagi-bagi ke dalam satuan waktu yang lebih kecil seperti tahun, bulan, atau hari. Atau, barangkali hal itu juga menjadi cermin dari sikap jujur mereka. Orang sebenarnya tidak tahu secara pasti berapa umurnya karena orang tidak tahu kapan ia lahir dan kapan akan berakhir hidupnya di dunia ini.

Cara berpikir yang berbeda pada orang Samin berkaitan dengan pemakaian leksikon tertentu dalam tuturan juga terlihat pada kasus berikut ini. Jika kebanyakan orang yang punya sapi ditanya berapa sapimu, orang tersebut akan menjawab dengan bilangan satu, dua, tiga, dan sebagainya sesuai dengan jumlah sapi yang dia miliki. Akan tetapi, orang Samin tidak demikian. Jika ditanya "Pira sapimu", ia akan menjawab sapi saya satu "Sapiku siji" meskipun kenyataannya sapi yang dia miliki lebih dari satu. Katakanlah, orang Samin yang ditanya tersebut memiliki tiga ekor sapi dan ditunjukkan kepadanya dengan menghitung sapinya, orang Samin tersebut tetap akan berkata bahwa sapinya satu. Sebab, yang kita hitung dengan bilangan tiga tadi baginya tetap sapi bukan binatang lain sehingga sapinya tetap satu. Dalam kasus ini tampaknya leksikon sapi dipahami sebagai leksikon yang bersifat generik.

\section{SIMPULAN}

Sebagai bagian dari penutur bahasa Jawa, tuturan mereka dapat dikatakan tidak berbeda dengan tuturan penutur bahasa Jawa lainnya yang tinggal di sekitar mereka. Hanya saja, untuk mengekspresikan hal tertentu mereka menggunakan leksikon yang khas.

Leksikon khas Samin sebenarnya juga dikenal oleh penutur bahasa Jawa yang lain, tetapi dengan makna yang berbeda. Perbedaan pemakaian leksikon tertentu antara penutur bahasa Jawa pada umumnya dengan masyarakat Samin ini dilatarbelakangi oleh perbedaan ideologi. Masyarakat Samin yang menganut ideologi Saminisme memandang sejumlah leksikon tertentu dalam bahasa Jawa kurang dapat mengekspresikan apa yang ingin mereka kemukakan sehingga mereka menggantinya dengan leksikon lain. Fenomena kebahasaan yang terdapat pada masyarakat Samin ini memberikan bukti terhadap teori dalam linguistik yang menyebutkan bahwa bahasa berkaitan dengan cara pandang penuturnya terhadap dunia luar, atau dengan kata lain bahasa mencerminkan pandangan dunia penuturnya.

\section{UCAPAN TERIMA KASIH}

Tulisan ini merupakan bagian dari hasil penelitian yang didanai oleh Fakultas Ilmu Budaya Universitas Gadjah Mada pada tahun 2012. Penulis mengucapkan terima kasih kepada Dekan dan Wakil Dekan bidang Penelitian dan Kerjasama FIB UGM yang telah memberi kepercayaan dan mengalokasikan dana untuk penelitian ini. Ucapan terima kasih juga disampaikan kepada pihak lain yang telah berkenan membantu pelaksanaan penelitian ini termasuk para informan Sedulur Sikep.

DAFTAR PUSTAKA

Ahearn, L.M. 2012. Living Language: An Introduction to Linguistic Anthropology. 
West Sussex: Wiley-Blackwell.

Boas, F. 1964a. "Linguistic and Ethnology". Dalam Dell Hymes (ed.). Language and Culture and Society. New York: Harper \& Row.

Boas, F. 1964b. “On Grammatical Categories". Dalam Dell Hymes (ed.). Language and Culture and Society. New York: Harper \& Row.

Foley, W.A. 1997. Anthropological Linguistics. Massachusetts: Blackwell Publisher Inc.

Mardikantoro, H.B. 2012. “Pergeseran Bahasa Jawa pada Masyarakat Samin di Kabupaten Blora". Disertasi. Fakultas Ilmu Budaya Universitas Gadjah Mada.

Sampson, G. 1980. Schools of Linguistics. London: Hutchinson.
Saussure, F. de. 1988. Pengantar Linguistik Umum. Diterjemahkan oleh Rahayu S. Hidayat. Yogyakarta: Gadjah Mada University Press.

Widodo, A. 1977. "Samin in the New Order: The Politics of Encounter and Isolation". Dalam Jim Schiller and Barbara Martin-Schiller (ed.). Imagining Indonesia: Cultural Politics and Political Culture. Ohio University Center for International Studies.

Wierzbicka, A. 1992. Semantics, Cognition and Culture. London: Oxford University Press.

Wierzbicka, A. 1997. Understanding Culture through Their Key Words. New York: Oxford University Press. 